\title{
Determinants of Small-Scale Mechanization for Potato Farming: A Case from Bangladesh
}

\author{
Moniruzzaman $^{1}$, Md. Sadique Rahman ${ }^{2 @}$, Md. Hayder Khan Sujan ${ }^{3}$ \\ ${ }^{1}$ Agricultural Economics Division, Bangladesh Agricultural Research Institute, Gazipur, Bangladesh; \\ monirecon44@yahoo.com \\ ${ }^{2}$ Department of Management and Finance, Sher-e-Bangla Agricultural University, Dhaka, Bangladesh; @ : \\ saadrhmn@yahoo.com, iD: https://orcid.org/0000-0001-8175-2164 \\ ${ }^{3}$ Department of Poverty and Development Studies, Sher-e-Bangla Agricultural University, Dhaka, Bangladesh; \\ mhksujan@gmail.com
}

Received 03 June, 2020., Revised 16 July, 2020 Accepted 03 April, 2021, Published 30 April, 2021

Scientific Editors: Krishna Prasad Timsina and Gokul Prasad Paudel

Copyright $(0) 2021$ NARC. Permits unrestricted use, distribution and reproduction in any medium provided the original work is properly cited.

The authors declare that there is no conflict of interest.

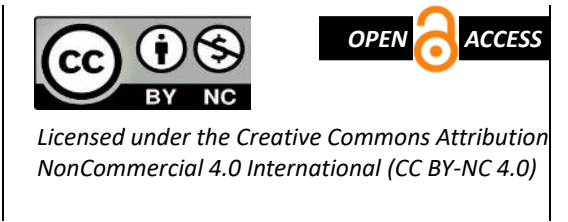

\section{ABSTRACT}

Identifying the determinants of farm mechanization can play a crucial role in the agriculture sector's development. The present study identifies the determinants of potato farm mechanization employing the ordered probit model. A total of 150 potato farmers were interviewed to achieve the objectives. The findings indicate that only around $13 \%$ of the respondents were high adopters. The adoption of potato farm mechanization was influenced by education, spouse education, farm size, and training. Marginal effect analysis suggested that farm size and training decrease the likelihood of being in the low adopter's category, respectively, by $13.2 \%$ and $10 \%$, while increases the likelihood of being in the high adopter's category by $7.5 \%$ and $5.7 \%$. Policy implications included more investment in extension facilities such as training from public agencies to sustain and increase adoption. Modifying the existing extension strategy by targeting not only primary farmers but also members of their families would help with the widespread adoption of farm mechanization.

Keywords: Adoption, farm mechanization, ordered probit model, potato

\section{सारांश}

कृषि यान्त्रीकरणका अवयवहरुको पहिचानले कृषि क्षेत्रको विकासको लािि महत्वपूर्ण भूमिका खेल्दछ। यो अध्ययनले आलुखेतीमा यान्त्रीकरणका लागि प्रयोग भइरहेको अर्डर प्रोविट मोडेलका अवयवहरुको पहिचान गर्दछ,। अध्ययनको उद्देश्य पूरा गर्न १४० जना आलु उत्पादक किसानहरुसँग अन्तरवार्ता लिइएको थियो। अध्ययनको नतिजाले के देखाउँछ भने जम्मा उत्तरदाताहरुमध्ये १३\% मात्र उच्च ग्रहणकर्ता थिए। आलुमा कृषि यान्त्रीकरणलाई ग्रहण गर्नको लागि ग्रहणकर्ताको शिक्षा, पति/पत्निको शिक्षा, फार्मको साइज र तालिमहरुले प्रभाव पारेको पाइयो। सिमान्तकृत असर विश्लेषण गर्दा फार्म साइज र तालिमको कारणले न्यून ग्रहणकर्ताको वर्ग कमशः १३. २\% ₹ १०\% ले घटेको पाइयो। जवकि उच्च ग्रहणकर्ताको वर्ग ऋमश: ७.५\% र ४..\% ले बढेको पाइयो। यान्त्रीकरणको ग्रहणलाई बढाउन र यसको दीगोपनाको लागि नीतिगत तहबाटै सार्वजनिक निकायको माध्यमबाट तालिम जस्ता कृषि प्रसारका सुविधाहरुमा लगानी अभ बढाउन पर्ने देखिन्छ। विद्यमान कृषि प्रसारको रणनीतिलाई रुपान्तरण गरी मुख्य किसानहरुका अलवा उनीहरुका परिवारका सदस्यहरुलाई पनि लक्षित गरी कार्यक्रम बनाउँदा कृषि यान्त्रीकरणको प्रयोग किसानस्तरमा व्यापक रुपमा बढ़न सक्छ।

\section{INTRODUCTION}

Bangladesh's agriculture is characterized by relatively small holdings and persistent fragmentation of land. Farm mechanization associated with the green revolution has affirmed the increase in production required to fulfill the food requirements (Adamade and Jackson 2014, McNulty and Grace 2009). Mechanization reduces peak season labour supply pressures, costs of production, and making farming attractive to youth people (Biggs and Justice 2015; Baudron et al 2015). Mechanization of agricultural 
operations such as land preparation, irrigation, and harvesting can greatly contribute to increase cropping intensity and production (Pingali 2007). Over time, various studies around the world have shown that farm mechanization plays a key role in increasing productivity, income, and the efficiency of agricultural practices (Aurangzeb et al 2007, Rahman et al 2011, Kienzle et al 2013, Benin 2015, Vortia et al 2019). Nowadays mechanization in land preparation and irrigation is very common in Bangladesh. However, mechanization in other agricultural operations such as planting and harvesting is still very low (Aryal et al 2019). Recently, various farm machinery, such as seed planter, thresher, harvester, etc., have been introduced into agricultural farming, special in potato farming, to enhance farm productivity in Bangladesh (Khalequzzaman and Karim 2007, Rahman et al 2011).

Potato (Solanum tuberosum L.), Bangladesh's third-largest food crop, has been grown as a cash crop across the country (Haque et al 2012, Sujan et al 2017). Adoption of mechanization in the growing cycle and harvesting can play a significant role in increasing the productivity of potatoes. Promotion of mechanization could be the effective means of reducing costs and alleviating labour shortages during potato planting and harvesting. Although two-wheeler tractor (power tiller) for land preparation and shallow tube-well for irrigation is well adopted in Bangladesh, the adoption of potato seeder and harvester lag behind its potential. Recently, the Farm Machinery and Postharvest Process Engineering (FMPE) division of Bangladesh Agricultural Research Institute (BARI) has developed potato seeder, and harvester to speed up the planting, and harvesting, reduce production costs and minimize labour shortage. The BARI potato planter machine can reduce planting costs by $67 \%$ and can be used effectively in small-scale areas (Anonymous 2017). In the manual potato harvesting system, potato beds must first be opened by an indigenous plough, then he/she uncovered potatoes picked up by hands, requiring labour and the costs. The BARI mechanized potato harvester can reduce labour costs by $70 \%$ and ensure maximum collection of potatoes from the field (Anonymous 2017). Out-migration of labours traditionally engaged in agriculture, due to better prospect in non-agricultural sectors, has also increased the need for mechanization (Biggs and Justice 2015).

Considering the role of mechanization in potato farming, it is important to understand the factors that affect adoption. A study conducted by Mottaleb et al (2016) identified the factors affecting the ownership of agricultural mercenaries such as irrigation pump, thresher, and power tiller in Bangladesh. However, estimates of the adoption of agricultural machinery based on ownership would largely underestimate actual use by farmers. Because most of the small farmers used hiring services to access agricultural machinery (Mottaleb et al 2017, Aryal et al 2019). Several other studies have been conducted to identify the determinants of farm mechanization around the world (Wang et al 2016, Gauchan and Shrestha 2017, Khondoker et al 2016, Alam and Khan 2017, Mandal 2017, Takele and Selassie 2018). But, failing to take into account the fact that mechanization is essentially a mixed package. Different operations and crops allow for specific mechanization alternatives. Crop specific farm mechanization strategies should be placed in place to boost the overall agricultural productivity and efficiency of Bangladesh (Rahman et al 2011). Most of the earlier studies consider power tiller and irrigation pump as an indicator of mechanization. This study contributes to the literature by taking into account all types of mechanization practices required for potato farming and classifying potato farmers based on these mechanized activities. Without defining the characteristics of adopters, extension activities will need more time and resources to reach the potato farmers. Identification of determinants also fills the gaps in knowledge for policymakers that may augment the further effective development of policies in Bangladesh. The research question, therefore, to understand this, is what are the factors that influence the adoption of mechanization in potato farming.

\section{MATERIALS AND METHODS}

\section{Data sources}

Three districts: Rajshahi, Rangpur, and Dinajpur were selected based on the highest contributors to potato production in Bangladesh. The list of potato farmers was collected from the local agricultural extension office, which serves as the sampling framework for the present study. Then, for each district, 50 potato farmers were randomly selected from that list. Thus, a total of 150 potato farmers were interviewed to achieve the objectives. The sample was classified into three groups: low adopters, 
medium adopters, and high adopters, based on the farm mechanization practices adopted. Potato farmers have generally adopted four types of mechanized practices: power tiller for land preparation, shallow tube-well for irrigation, potato seeder for planting, and potato harvester. A potato grower has been assigned to the low adopter category if he adopted power tiller and shallow tube-well because these two practices are available and well adopted in Bangladesh. A farmer who has adopted either a seeder or a harvester and all the practices of low adopter category has been considered as a medium adopter, whereas a farmer has been assigned into high adopter category if he has adopted all the four mechanized practices. Data was collected through a face-to-face interview in 2015. Interview schedule consisting of questions on the socio-demographic profile of respondents, income, cost, and return of potato farming. To analyze the data, STATA was used.

\section{Model specification}

The study used a random utility framework to analyze the farmer's decision to adopt mechanized practices (Fischer and Qaim 2012, Abebaw and Haile 2013). According to this framework, farmers choose to adopt mechanized practices if the utility gained from adoption is higher than non-adoption. This utility gain can be expressed as a function of various explanatory variables $\left(X_{i}\right)$ in the following type of latent variable model;

$Y_{i}^{*}=\beta X_{i}+\epsilon_{i}$

Where, $Y_{i}^{*}$ is the dependent variable (adoption categories); $\beta$ is the parameter to be estimated, and $\epsilon_{i}$ is the error term. Several studies (Ghose 2010, Ghimire et al 2015, Takele and Selassie 2018) used binary probit or logit model to find out the determinants of adoption ignoring the fact that farmers may exhibit a different level of adoption decision. A probit or logit model, with values of 0 or 1 , is not appropriate when the dependent variable has more than two values. Mechanization is not a single measure where the farmer just decides whether to adopt or not. Rather, mechanization is a package of different practices. Therefore, it is not suitable to label two farmers just as adopters when they might exhibit a different level of adoption. Thus, to overcome the problem of binary probit or logit model, in this study we used the ordered probit model, which allows the dependent variable to take more than two discrete values (Abdel-Aty 2001, Boz and Akbay 2005, Teklewold et al 2013, Hasan 2017). In this study, the dependent variable represents ordered responses depending on the types of the mechanized practices adopted by a potato farmer. The sign of the parameter estimates readily tells us whether an independent variable has a positive or a negative effect on the probability of adoption. The dependent variable was coded as 1 =low adopters, $2=$ medium adopters, and $3=$ high adopters. The log-likelihood function was estimated as:

$L=\sum_{j=1}^{j} \sum_{y_{i}=j} \log \left(\Phi\left(\mu_{j}-\beta_{i} X_{i}\right)-\Phi\left(\mu_{1}-\beta_{i} X_{i}\right)\right)$

Where $j$ is the group category $(0-3), \mu$ is the threshold values, $\Phi$ is the cumulative standard function of a standard normal distribution.

\section{Explanation of the explanatory variables}

The adoption of new technology is generally influenced by different factors, such as farm and sociodemographic characteristics, economic factors, information transformation mechanisms, and institutional factors (Mendola 2007, Awotide et al 2014). The selection of the explanatory variables for this study was based on the previous literature and prior expectations (Rahman et al 2011, Aryal et al 2019). Description of the explanatory variables used in our model is given in Table 1. 
Table 1. Description of the explanatory variables

\begin{tabular}{llc}
\hline Variable & \multicolumn{1}{c}{ Description } & Expected sign \\
\hline Experience (yrs) & Farming experience in years of the primary farmer. & + - \\
\hline Education (yrs) & Total years of schooling of the primary farmer. & + \\
\hline Spouse education (yrs) & Total years of schooling of the primary farmer's spouse. & + \\
\hline Farm size (hectare) & Total farm size in a hectare. & $+/-$ \\
\hline Training (days) & $\begin{array}{l}\text { The total number of days spends on training during the last } \\
12 \text { months. }\end{array}$ & + \\
\hline $\begin{array}{l}\text { Societal membership } \\
\text { (dummy) }\end{array}$ & $\begin{array}{l}\text { One, if the primary farmer is involved in any societal } \\
\text { organization, otherwise 0. }\end{array}$ & + \\
\hline $\begin{array}{l}\text { Distance from highway } \\
\text { (km) }\end{array}$ & $\begin{array}{l}\text { Distance of farm from the highway in kilometers, used as a } \\
\text { proxy of market accessibility. }\end{array}$ & + \\
\hline $\begin{array}{l}\text { Income (000 Tk.) } \\
\text { Total annual income from agricultural and non-agricultural } \\
\text { sources. }\end{array}$ & + \\
\hline $\begin{array}{l}\text { Field day participation } \\
\text { (dummy) }\end{array}$ & $\begin{array}{l}\text { One, if the primary farmer has credit access to any formal } \\
\text { institution, otherwise } 0 .\end{array}$ \\
\hline
\end{tabular}

\section{RESULTS}

Descriptive statistics of the selected variables

Table 2 gives a summary of the descriptive statistics of the socio-economic characteristics of the respondents. Out of 150 potato farmers, only 20 farmers were high adopters. About $67 \%$ of the farmers were in the low adopter category. The findings indicate that there are variations in the selected characteristics. High adopters were more experienced than the other two groups of potato farmers. The average schooling year was much higher for the high adopter's group (8.75) compared to the low adopters (4.68). Farm size was also higher for high adopters, indicating that large potato farms were more mechanized. Medium and high adopters spend more days in training relative to low adopter's group, which can augment their adoption decision. The high adopter's group was also significantly distinguishable in terms of credit access.

Table 2. Descriptive statistics of the variables

\begin{tabular}{lcccccc}
\hline \multirow{2}{*}{ Variables } & \multicolumn{2}{c}{$\begin{array}{c}\text { Low adopters } \\
(\mathbf{n = 1 0 0})\end{array}$} & \multicolumn{2}{c}{$\begin{array}{c}\text { Medium adopters } \\
(\mathbf{n = 3 0})\end{array}$} & \multicolumn{2}{c}{$\begin{array}{c}\text { High adopters } \\
(\mathbf{n}=\mathbf{2 0})\end{array}$} \\
\cline { 2 - 7 } & Mean & SE & Mean & SE & Mean & SE \\
\hline Experience (yrs) & 16.00 & 8.06 & 15.49 & 5.57 & 18.30 & 4.97 \\
\hline Education (yrs) & 4.68 & 4.03 & 8.20 & 2.88 & 8.75 & 2.05 \\
\hline Spouse education (yrs) & 2.69 & 3.59 & 4.00 & 3.94 & 5.25 & 4.53 \\
\hline Farm size (ha.) & 1.03 & 0.45 & 1.26 & 0.60 & 1.89 & 1.10 \\
\hline Training (days) & 0.61 & 0.98 & 2.11 & 1.18 & 2.00 & 1.12 \\
\hline Societal membership (dummy) & 0.35 & 0.48 & 0.37 & 0.49 & 0.45 & 0.51 \\
\hline Distance from highway (km) & 2.52 & 1.77 & 2.19 & 0.94 & 1.88 & 1.17 \\
\hline Income (000 Tk.) & 268.38 & 116.52 & 324.95 & 123.79 & 231.91 & 72.83 \\
\hline Access to credit (dummy) & 0.21 & 0.41 & 0.43 & 0.50 & 0.45 & 0.51 \\
\hline Field day participation (dummy) & 0.19 & 0.39 & 0.29 & 0.46 & 0.25 & 0.44 \\
\hline SE & & & & & &
\end{tabular}

SE indicates standard error.

\section{Determinants of adoption}

The results in Table 3 represent the ordered probit model analysis used to estimate the determinants of adoption. The model $\chi^{2}$ is statistically significant at the $1 \%$ level. The estimated cutoff values are positive and statistically significant, suggesting that there is a natural ordering between the groups. Of the 11 explanatory variables, 5 have had a positive influence on the adoption decision. Education, spouse education, farm size, and training are significant at $1 \%$ level. 
The marginal effects for all explanatory variables are presented in Table 4. The marginal effect of experience indicates that 1-year increase in farming experience decreases the likelihood of being in low adopter's category by $0.7 \%$. However, 1 -year increase in farming experience increases the likelihood of being in the medium adopter's category by $0.3 \%$. The marginal effect of education indicates that 1 year increase in education would decrease the likelihood of being in the low adopter's category by $3.6 \%$. On the other hand, 1-year increase in education increases the likelihood of being in the medium and high adopter's category by $1.6 \%$, and $2.1 \%$, respectively. Similarly, the marginal effect of spouse education indicates that 1-year increase in spouse education increases the likelihood of being in high adopter's category by $1.2 \%$. The marginal effect analysis of farm size indicates that 1 -hectare increase in farm size decreases the likelihood of being in low adopter's category by $13.2 \%$, whereas 1-hectare increase in the farm size increases the likelihood of being in medium and high adopter's category, respectively, by $5.6 \%$, and $7.5 \%$. Findings also indicate that 1 more day spends in training increases the likelihood of being in the high adopter category by $5.7 \%$, whereas 1 more day in training in the low adopter category decreases the likelihood of being in the low adopter category by $10 \%$.

Table 3. Factors affecting adoption of potato farm mechanization

\begin{tabular}{lcc}
\hline Variable & Coefficient & Robust SE \\
\hline Experience (yrs) & $0.027^{*}$ & 0.016 \\
\hline Education (yrs) & $0.150^{* * *}$ & 0.036 \\
\hline Spouse education (yrs) & $0.090^{* * *}$ & 0.033 \\
\hline Farm size (ha.) & $0.544 * * *$ & 0.187 \\
\hline Training (days) & $0.414^{* * *}$ & 0.105 \\
\hline Societal membership (dummy) & -0.066 & 0.263 \\
\hline Distance from highway (km) & -0.125 & 0.092 \\
\hline Income (000 Tk.) & 0.001 & 0.001 \\
\hline Access to credit (dummy) & 0.386 & 0.257 \\
\hline Field day participation (dummy) & -0.055 & 0.259 \\
\hline Threshold 1 & $2.99 * * *$ & 0.57 \\
\hline Threshold 2 & $4.35 * * *$ & 0.65 \\
\hline Log likelihood & & \\
\hline LR chi square & & -83 \\
\hline Pseudo R & & \\
\hline Note: $*$ and $* * *$ indicate significant at 10\%, and 1\% level, respectively. & 0.33 \\
\hline
\end{tabular}

Note: *, and *** indicate significant at $10 \%$, and $1 \%$ level, respectively.

Table 4. Marginal effect of factors affecting adoption

\begin{tabular}{lccc}
\hline \multirow{2}{*}{ Variables } & \multicolumn{3}{c}{ Marginal effect } \\
\cline { 2 - 4 } & Low adopters & Medium adopters & High adopters \\
\hline Experience (yrs) & $-0.007^{*}$ & $0.003^{*}$ & 0.004 \\
\hline Education (yrs) & $-0.036^{* * *}$ & $0.016^{* * *}$ & $0.021^{* * *}$ \\
\hline Spouse education (yrs) & $-0.022^{* * *}$ & $0.009^{* * *}$ & $0.012^{* * *}$ \\
\hline Farm size (ha.) & $-0.132^{* * *}$ & $0.056^{* * *}$ & $0.075^{* * *}$ \\
\hline Training (days) & $-0.100^{* * *}$ & $0.043^{* * *}$ & $0.057^{* * *}$ \\
\hline Societal membership (dummy) & 0.016 & -0.007 & -0.009 \\
\hline Distance from highway (km) & 0.030 & -0.013 & -0.017 \\
\hline Income (000 Tk.) & -0.000 & 0.000 & 0.001 \\
\hline Access to credit (dummy) & -0.093 & 0.040 & 0.053 \\
\hline Field day participation (dummy) & 0.013 & -0.006 & -0.008 \\
\hline Not:
\end{tabular}

Note: *, and *** indicates significant at $10 \%$, and $1 \%$ level, respectively.

\section{DISCUSSION}

Findings indicate that the overall adoption of various mechanized practices for potato farming in Bangladesh is low. Most of the farmers had adopted only power tiller and shallow tube-well. This may be because mechanized practices such as potato seeder and harvester are not available in the farmer's 
field. The economic conditions of the farmers can also prevent them from investing in such mechanized practices.

A significant and positive coefficient of experience indicates that experienced farmers are more likely to be high adopters. Similarly, positive and significant coefficients of education, spouse education, farm size, and training indicate that these variables have a positive influence on the likelihood of being in the high adopter's category. Education helps farmers to understand the benefits of new technology (Alene and Manyong 2007). The positive and significant influenced of spouse education is consistent with the findings of Aryal et al (2019). Respondents who have an educated spouse can consult with them on the benefits and limitations of new technology that can increase adoption. A positive and significant coefficient of farm size indicates that farm mechanization is more prevalent among large farmers, confirms the findings of Ghosh (2010) and Mottaleb et al (2016). The findings indicate that enlargement of farm size as an important aspect of farm mechanization. The farmers who have larger farms benefit more compared to small farmers due to the need for timely farming operations to prevent labour crisis during peak times (Aryal et al 2019). The lands are generally small and fragmented in Bangladesh, which restricts the farmers to use a larger size of farm machinery (Islam 2018). However, smallholder farmers are willing to adopt mechanized technologies when the technology is scale-appropriate (Paudle et al 2019a, Paudle et al 2019b). A significant and positive coefficient of training is consistent with the findings of other studies (Kabir and Rainis 2015, Aryal et al 2019) indicated that farmers with more days in training are more likely to adopt agricultural technologies. Training is one of the ways of empowering farmers with knowledge, which is a prerequisite for better farming performance. Training helps farmers to diversify their knowledge and encourage farmers to adopt more.

\section{CONCLUSIONS}

The present study identifies the determinants of mechanization in potato farming using cross-sectional data collected through a face-to-face interview. The results of the study suggested that only about $13 \%$ of the respondents were high adopters. Experience, education, spouse education, and training have played a significant role in adoption. Investment in extension services, such as training, field visits, and demonstrations, is needed to increase the awareness and thus, the adoption. Modification of the existing extension approach by targeting the family members, special spouse of the potato farmers, may help the widespread adoption of farm mechanization. More visits to the villages by the extension staffs may ease the process of adoption. Our findings indicate that the farm size has had a positive influence on adoption. Since farmers in Bangladesh are smallholders, the emphasis should be given on small-scale machinery for widespread adoption. Nonetheless, this study has limitations. Only a small number of potato farmers were considered in this study. A large-scale survey can be useful in developing a complete scenario for mechanization in Bangladesh.

\section{ACKNOWLEDGEMENTS}

Thanks and appreciation are extended to the respondents and the enumerators for their excellent support during data collection.

\section{REFERENCES}

Abdel-Aty MA. 2001. Using ordered probit modeling to study the effect of ATIS on transit ridership. Transportation Research Part C: Emerging Technologies. 9(4): 265-277.

DOI: https://doi.org/10.1016/S0968-090X(00)00037-1

Abebaw D and GM Haile. 2013. The impact of Cooperatives on agricultural technology adoption: empirical evidence from Ethiopia. Food Policy. 38: 82-91. DOI: https://doi.org/10.1016/j.foodpol.2012.10.003

Adamade CA and BA Jackson. 2014. Agricultural mechanization: A strategy for food sufficiency. Journal of Agricultural Science. 4(3): 152-156.

Alam M and IN Khan. 2017. Agricultural mechanization: Status, challenges and opportunities in Bangladesh. In: T.R. Gurung, W. Kabir, S.M. Bokhtiar (Eds.) Mechanization for sustainable agricultural intensification in SAARC region, SAARC Agriculture Centre, Dhaka, Bangladesh 2017, pp. 41-70.

Alene AD and VM Manyong. 2007. The effects of education on agricultural productivity under traditional and improved technology in northern Nigeria: an endogenous switching regression analysis. Empirical Economics. 32: 141-159. DOI: https://doi.org/10.1007/s00181-006-0076-3 
Anonymous. 2017. Introduction to BARI developed agricultural machinery. Publication No. 15bklt/2016-17, Farm Machinery \& Postharvest Process Engineering Division, Bangladesh Agricultural Research Institute, Bangladesh.

Aryal JP, DB Rahut, S Maharjan and O Erenstein. 2019. Understanding factors associated with agricultural mechanization: a Bangladesh case. World Development Perspective. 13: 1-9.

DOI: https://doi.org/10.1016/j.wdp.2019.02.002

Aurangzeb M, S Nigar and M Khan. 2007. Labour requirement model for the wheat crop under mechanized and traditional farming systems in the NWFP: A case study of Peshwar districts. Sarhad Journal of Agriculture. 23(1): 177-186.

Awotide BA, T Abdoulaye, A Alene and VM Manyong. 2014. Assessing the extent and determinant of adoption of improved cassava varieties in South-western Nigeria. Journal of Development and Agricultural Economics. 6(9): 376-385. DOI: https://dx.doi.org/10.5897/JDAE2014.0559

Baudron F, B Sims, S Justice, DG Kahan, R Rose, S Mkomwa, P Kaumbutho, J Sariah, R Nazare, G Moges and B Gérard. 2015. Re-examining appropriate mechanization in Eastern and Southern Africa: two-wheel tractors, conservation agriculture, and private sector involvement. Food Security. 7: 889-904.

DOI: https://doi.org/10.1007/s12571-015-0476-3

Benin S. 2015. Impact of Ghana's agricultural mechanization services center program. Agricultural Economics. 46: 103-117. DOI: https://doi.org/10.1111/agec.12201

Biggs S and S Justice. 2015. Rural and Agricultural Mechanization: A History of the Spread of Small Engines in Selected Asian Countries. IFPRI Discussion Paper 01443, Development Strategy and Governance Division. International Food Policy Research Institute, Washington, DC.

Boz I and C Akbay. 2005. Factors influencing the adoption of maize in Kahramanmaras province of Turkey. Agricultural Economic. 33: 431-440. DOI: https://doi.org/10.1111/j.1574-0864.2005.00305.x

Fischer E and M Qaim. 2012. Linking Smallholders to Markets: Determinants and Impacts of Farmer Collective Action in Kenya. World Development. 40(6): 1255-1268.

DOI: https://doi.org/10.1016/j.worlddev.2011.11.018

Gauchan D and S Shrestha. 2017. Agricultural and rural mechanization in Nepal: status, issues and options for future, In: M.A.S. Mandal, S.D., Biggs, S.E. Justice (Eds.), Rural Mechanization. A Driver in Agricultural Change and Rural Development, Institute for Inclusive Finance and Development, Dhaka, Bangladesh, 2017, pp. 97-118.

Ghimire R, H Wen-chi and BR Shrestha. 2015. Factors affecting adoption of improved rice varieties among rural farm households in Central Nepal. Rice Science. 22: 35-43.

DOI: https://doi.org/10.1016/j.rsci.2015.05.006

Ghosh BK. 2010. Determinants of farm mechanization in modern agriculture: A case study of Burdwan districts of West Bengal. International Journal of Agricultural Research. 5: 1107-1115.

Islam AKMS. 2018. Status of rice farming mechanization in Bangladesh. Journal of Bioscience and Agricultural Research. 17(1): 1386-1395.

Haque MA, MAM Miah, S Hossain and MM Rahman. 2012. Profitability of BARI released potato (Solanum tuberosum L.) varieties in some selected locations of Bangladesh. Bangladesh Journal of Agricultural Research. 37(1): 149-158.

Hasan SMM. 2017. Factors Affecting Integrated Pest Management (IPM) Adoption and Pesticide Use in Kenyan Vegetable Farmers. MS Thesis, Dept. of Agricultural and Applied Economics, Virginia Tech University, Blacksburg, USA.

Kabir MK and R Rainis. 2015. Adoption and intensity of integrated pest management (IPM) vegetable farming in Bangladesh: an approach to sustainable agricultural development. Environment Development Sustainability. 17: 1413-1429. DOI: https://doi.org/10.1007/s10668-014-9613-y

Khalequzzaman KM and MA Karim. 2007. Study of agricultural mechanization and its impact on rural environment. Journal of Innovative Development Strategy. 1(1): 37-40.

Khondoker AM, J Timothy and OE Krupnik. 2016. Factors associated with small-scale agricultural machinery adoption in Bangladesh: Census findings. Journal of Rural Studies. 46: 155-168.

Kienzle J, JE Ashburner and BG Sims. 2013. Mechanization for rural development: a review of patterns and progress from around the world. FAO, Rome, Italy.

Mandal, MAS. 2017. Growth of mechanization in Bangladesh agriculture: Role of policies and missing links, In: MAS Mandal, SD Biggs, SE Justice (Eds.), Rural Mechanization. A Driver in Agricultural Change and Rural Development, Institute for Inclusive Finance and Development, Dhaka, Bangladesh.

McNulty PB and PM Grace. 2009. Agricultural mechanization and automation, $2^{\text {nd }}$ ed, Encyclopedia of Life Support Systems (EOLSS), Paris.

Mendola M. 2007. Agricultural technology adoption and poverty reduction: A propensity-score matching analysis for rural Bangladesh. Food Policy. 32: 372-393. DOI: https://doi.org/10.1016/j.foodpol.2006.07.003 
Mottaleb KA, TJ Krupnik and O Erenstein. 2016. Factors associated with small-scale agricultural machinery adoption in Bangladesh: Census findings. Journal of Rural Studies. 46: 155- 168.

DOI: http://dx.doi.org/10.1016/j.jrurstud.2016.06.012

Mottaleb KA, DB Rahut, A Ali, B Gérard and O Erenstein. 2017. Enhancing smallholder access to agricultural machinery services: lessons from Bangladesh. The Journal of Development Studies. 53: 1502-1517.

DOI: https://doi.org/10.1080/00220388.2016.1257116

Paudel GP, DB KC, DB Rahut, SE Justice and AJ McDonald. 2019a. Scale-appropriate mechanization impacts on productivity among smallholders: evidence from rice systems in the mid-hills of Nepal. Land Use Policy. 85: 104-113. DOI: https://doi.org/10.1016/j.landusepol.2019.03.030

Paudel GP, DB KC, DB Rahut, NP Khanal, SE Justice and AJ McDonald. 2019b. Smallholder farmers' willingness to pay for scale-appropriate farm mechanization: Evidence from the mid-hills of Nepal. Technology in Society. 59. DOI: https://doi.org/10.1016/j.techsoc.2019.101196

Pingali P. 2007. Agricultural mechanization: adoption patterns and economic impact, In: R Evenson and P Pingali (Eds.), Handbook of agricultural economics, Vol 3, pp. 2779-2805.

Rahman MS, MAM Miah, Moniruzzaman and S Hossain. 2011. Impact of farm mechanization on labour use for wheat cultivation in northern Bangladesh. The Journal of Animal \& Plant Sciences. 21(3): 589-594. http://www.thejaps.org.pk/docs/21-3/30.pdf

Sujan HK, F Islam, MMH Kazal and RK Mondal. 2017. Profitability and resource use efficiency of potato cultivation in Munshiganj district of Bangladesh. SAARC Journal of Agriculture. 15(2): 193-206.

Takele A and YG Selassie. 2018. Socio-economic analysis of conditions for adoption of tractor hiring services among smallholder farmers, Northwestern Ethiopia, Cogent Food \& Agriculture. 4:1.

DOI: https://doi.org/10.1080/23311932.2018.1453978

Teklewold H, M Kassie and B Shiferaw. 2013. Adoption of Multiple Sustainable Agricultural Practices in Rural Ethiopia. Journal of Agricultural Economics. 64(3): 596-623. DOI: https://doi.org/10.1111/14779552.12011

Vortia P, M Nasrin, SK Bipasha and MM Islam. 2019. Extent of farm mechanization and technical efficiency of rice production in some selected areas of Bangladesh. Geo Journal.

DOI: https://doi.org/10.1007/s10708-019-10095-1

Wang X, F Yamauchi, K Otsuka and J Huang. 2016. Wage growth, landholding, and mechanization in Chinese agriculture. World Development. 86: 30-45. DOI: https://doi.org/10.1016/j.worlddev.2016.05.002

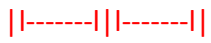

